\title{
Range use by an adult male caracal in the southern Kalahari
}

\author{
J. DU P. BOTHMA and E.A.N. LE RICHE
}

\begin{abstract}
Bothma, J. du P. and E.A.N. le Riche. 1994. Range use by an adult male caracal in the southern Kalahari. Koedoe 37(2): 105-108. Pretoria. ISSN 0075-6458.

Key words: caracal, Felis caracal, Kalahari, range, aerial tracking.

J. du P. Bothma, Centre for Wildlife Management, University of Pretoria, Pretoria, 0002 Republic of South Africa; E.A.N. le Riche, Kalahari Gemsbok National Park, Private Bag X 5890, Gemsbokpark, 8815 South Africa.
\end{abstract}

The home range of felids is largely determined by factors related to hunting success, but especially to the number of hunting places, cover and prey abundance (Kruuk 1986). In arid areas with a variable prey base and relatively sparse cover, it can therefore be expected that felid range sizes will be greater than elsewhere for the same species. This hypothesis is examined here, using data from a single adult male caracal Felis caracal radio-tracked in the south-western part of the Kalahari Gemsbok National Park of South Africa from 26 January 1990 to 12 August 1991.

The caracal was captured on 26 January 1990 south-west of Hakskeenpan, on the park boundary with the Mier area, in the red dunes of the south-western part of the park. It was radio-collared and then released at Kamqua in the Auob riverbed (Fig. 1). The collar was one of a range of Telonics collars, the others being used on leopards, operating on frequencies from 148-150 MHz. Aerial tracking was done using a Cessna 206.

Tracking of the caracal was done at irregular intervals. A cabin-mounted left-right switch and circling manoeuvres with the aircraft helped to pinpoint the locality concerned.

Localities (Fig. 1) were transformed into local origin data and were plotted with the use of the Microstation PC version 4.0123 programme. The surface areas concerned were calculated using standard measuring tools/utilities available in the GIS system. The surface areas of the observed range and the core area of the range, as given here, were based on the minimum area convex polygon concept of Möhr (1947). This facilitated comparison with the results of Stuart (1982), Norton \& Lawson (1985), Moolman (1986) and Avenant (1993), the only known published studies giving the surface area of the range for South African caracals to date.

The approach of Hamilton (1976) is used here for the observed range. The core area is an area with an obvious clumping of plots (Stuart 1982; Norton \& Lawson 1985). Of the 18 plots obtained here, 13 were located in the core area, but as some of these localities were duplicated, only ten appear in Figure 1. 


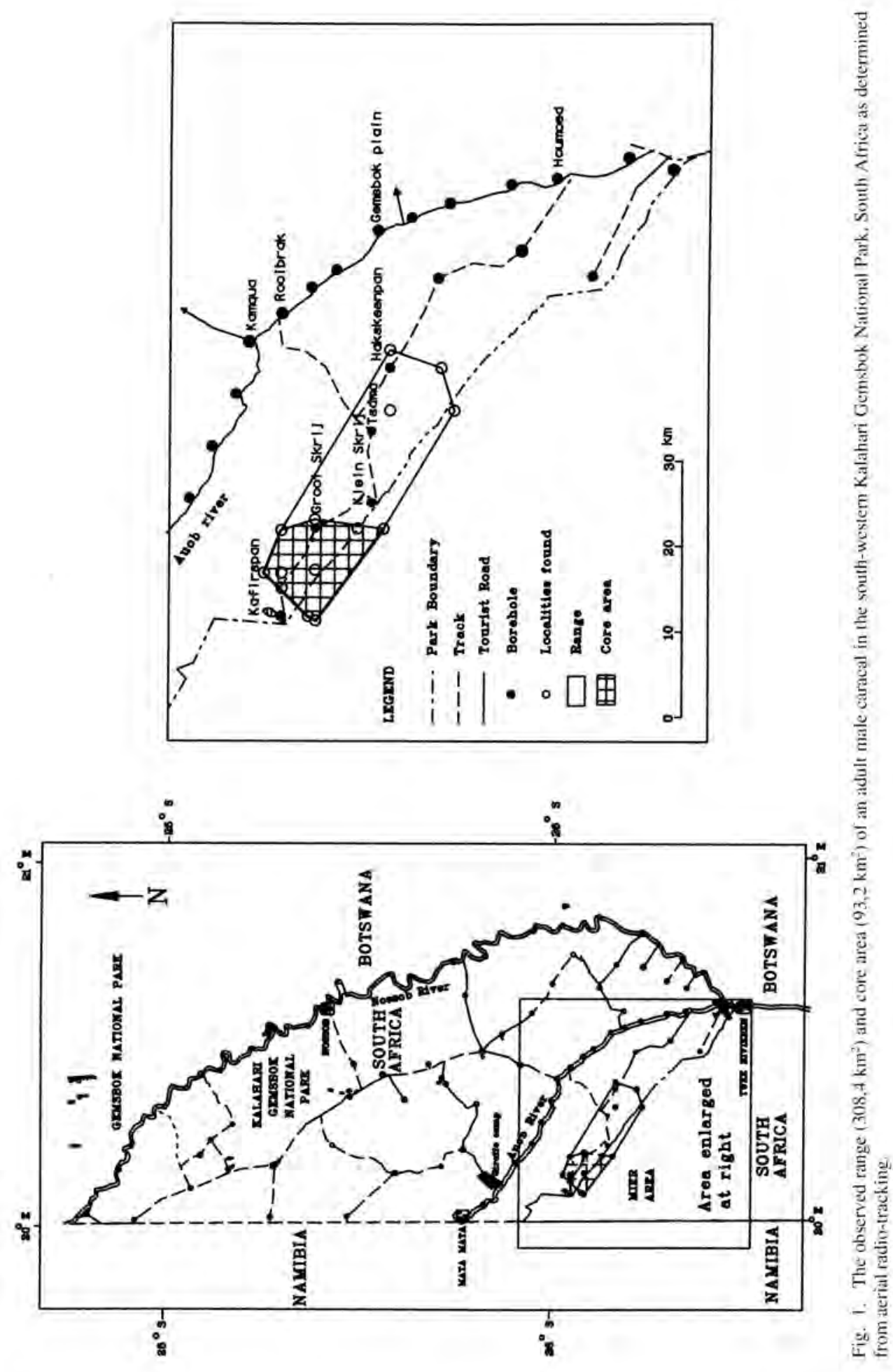


The results indicated a core area of $93,2 \mathrm{~km}^{2}$ and an observed range of $308,4 \mathrm{~km}^{2}$. Norton \& Lawson (1985) tracked a young caracal male in the south-western Cape. The caracal settled into a mean range of $65 \mathrm{~km}^{2}$ for 11 months after moving around extensively $\left(483 \mathrm{~km}^{2}\right)$, as young dispersing felid males do when seeking an own permanent territory. No core area calculation was done by Norton \& Lawson (1985). Moolman (1986) studied seven adult male caracals in the Mountain Zebra National Park and its environs. The four whose movements were limited to the park, had a mean range of 15,2 $\pm 2,02 \mathrm{~km}^{2}$ which differed significantly from the 19,1 \pm $12,92 \mathrm{~km}^{2}$ of the three males limited to the surrounding farms. Using a one-sided $t$-test, the range size of the Kalahari caracal, as calculated here, also differed significantly from the mean range size of the male caracals in the Mountain Zebra National Park $(t=$ $-12,9 ; d f=3, p<0,01)$. Male caracal ranges in the Mountain Zebra National Park showed a mean overlap of 142,1 ha $(9,3 \%)$ in surface area, but again no core area sizes are given although they are indicated on caracal rangeuse maps (Moolman 1986). Stuart (1982) only gives range-use data for female caracals which are known to have smaller and more overlapping ranges than males (Moolman 1986). Avenant (1993), who worked on caracals in the West Coast National Park, found a mean range size of $26,97 \mathrm{~km}^{2}$ for two males and $7,39 \mathrm{~km}^{2}$ for three females. The maximum home range for a given male was 32,87 $\mathrm{km}^{2}$. No data are given on core area sizes.

The data given here are the first for the extremely arid south-western portion of the south-western Kalahari. The range, of the male involved, included $61,4 \mathrm{~km}^{2}(19,9 \%$ of the total range) of the adjacent Mier farming area. It also included four known waterholes, although the caracal is water-independent (Smithers 1983). The northern boundary of the range roughly parallelled the Auob riverbed. The whole range was used during the observation period. The last two localities, situated at the two range extremes, i.e. $2 \mathrm{~km}$ east of Hakskeenpan and $5 \mathrm{~km}$ east of Groot
Skrij, were visited within a period of 22 days (Fig. 1). The return of the caracal, over a straight line distance of some $25 \mathrm{~km}$ from its release site at Kamqua to near its capture site, is indicative of homing behaviour and range integrity.

Although Jennrich \& Turner (1969) stated that some bias becomes noticeable in the minimum area method of range size calculation when it is based on $<25$ plots, the results given here, based on 18 plots, are probably a fair estimation of the average adult male caracal's movements in the study area. Gittleman \& Harvey (1982), by implication, stated that home range size in carnivores will increase in size when food becomes limited. In arid areas, food resources are limited, and the present study gives a clue to the parameters of observed range and core area size required in the arid Kalahari to support an adult male caracal. This area is much larger than any home range previously known for caracals in the Cape Province.

The National Parks Board of South Africa gave permission to do the research, and with the University of Pretoria, assisted us financially. S van Hoven prepared Fig. 1 and operated the GIS system involved, while L Swanepoel typed the manuscript. We thank them all sincerely.

\section{References}

Avenant, N.L. 1993. The caracal, Felis caracal caracal Schreber, 1776, as predator in the West Coast National Park. MSc thesis, University of Stellenbosch, Stellenbosch.

Gittleman, J.L. and P.L. Harvey. 1982. Carnivore home range size, metabolic needs and ecology. Behavioural Ecology and Sociobiology 10: 5763.

Hamilton, P.H. 1976. The movements of leopards in Tsavo National Park, Kenya, as determined by radio-tracking. MSc thesis, University of Nairobi, Nairobi.

JENNRICH, R.I. AND F.B. TURNER. 1969. Measurement of non-circular home range. Journal of Theoretical Biology 22: 227-237.

KruUk, H. 1986. Interactions between Felidae and their prey species: a review. Pp. 353-374. In: S.D. Miller And D.D. Everett (eds.). Cats of the 
World: Biology, Conservation and Management, Washington, D.C.: National Wildlife Federation. Moolman, L.C. 1986. Aspekte van die ekologie en gedrag van die rooikat Felis caracal Schreber, 1776 in die Bergkwagga Nasionale Parken op die omliggende plase. MSc thesis, University of Pretoria, Pretoria.

Norton, P.M. AND A.B. Lawson. 1985. Radio-tracking of leopards and caracals in the Stellenbosch area, Cape Province. South African Journal of Wildlife Research 15(1): 17-24.

SMITHERS, R.H.N. 1983. The mammals of the southern African subregion. Pretoria: University of Pretoria.

StuART, C.T. 1982. Aspects of the biology of the caracal (Felis caracal Schreber, 1776) in the Cape Province, South Africa. MSc thesis, University of Natal, Pietermaritzburg. 